\title{
Analysis on the Construction Background of Hunan HG Logistics Center and Its Necessity and Feasibility*
}

\author{
Shijun Yuan \\ Hunan Vocational College of Modern Logistics \\ Changsha, China 410131
}

\author{
Jianhua Chen** \\ Hunan Vocational College of Modern Logistics \\ Changsha, China 410131 \\ **Corresponding Author
}

\begin{abstract}
Based on the analysis of the status quo of radiation regional logistics development and the role and significance of logistics center construction in Hunan HG Logistics Center, the author further analyzed the feasibility from the aspects of macro policy environment, economic environment, enterprise operation capability, capital strength and customer group.
\end{abstract}

Keywords—logistics center; necessity; feasibility; analysis

\section{INTRODUCTION}

The construction of Hunan HG Logistics Center is an important investment attraction project. Its main mission is not only limited to the specific operation of enterprise logistics services in the logistics center, but the establishment of a basic platform and operation base for the development of modern logistics in the city and guiding and supporting the city's modern logistics enterprises. Relying on the infrastructure and policy environment conditions of the logistics center, establish a modern logistics operation system within the city.

\section{ANALYSIS OF THE OUTSTANDING PROBLEMS IN THE} DEVELOPMENT OF THE LOGISTICS INDUSTRY IN THE PROJECT

\section{RADIATION AREA}

\section{A. The Basic Conditions of Logistics Are Still Weak}

The domestic railway-rail transportation system has just started, and there is no air transportation, what's more, the construction of logistics supporting facilities is obviously lagging behind. So the three-dimensional transportation system with wide radiation range and convenient and efficient operation has not yet formed. The logistics and storage facilities are seriously inadequate, the level of mechanization of shipment is low, and the original mode of manual loading and unloading has not been rid of. The construction of logistics network information has not yet started, which restricts the function of logistics and the improvement of efficiency.

\section{B. The Logistics Cost Is High, the Logistics Enterprise Business Model Needs to Be Improved, and the Degree of Intensification Needs to Be Promoted}

Internationally, the proportion of logistics cost to GDP is usually used as an important indicator to measure logistics efficiency and benefits. The indicator in developed countries and regions that have implemented modern logistics has been controlled at around $10 \%$ (1.5\% in the US, $11.4 \%$ in Japan, $13.1 \%$ in Taiwan, $13.9 \%$ in Singapore, and $13.7 \%$ in Hong Kong). The logistics cost of the project area is $19.4 \%$ of GDP, and the logistics cost is twice that of developed countries. Generally speaking, the business model of most logistics enterprises in the project radiation area is still at a relatively extensive and preliminary stage. The modern logistics concept has not yet formed, the enterprise service capacity is not strong, the degree of intensification is low, and the quality and benefits need to be improved.

\section{There Are Certain Difficulties in the Development of Third-party Logistics Companies}

At present, some industrial and commercial enterprises have not completely shaken off the influence of the planned economy. They have not integrated and reorganized the internal logistics of enterprises according to the modern logistics concept. They are used to the business model of "to be big and complete" and "to be small but complete". There are many self-run logistics and they are usually small, scattered and weak, which has led to the inefficient use of some modern logistics facilities, and the difficulties of the development of third-party logistics companies. Self-run logistics in the enterprise has its convenience, but from the perspective of the whole society, this is uneconomical, the waste of logistics resources is serious, and the logistics facilities are not reasonable. According to the survey of major supermarkets in the project radiation area, most of them sign contracts with suppliers, and delivered by suppliers directly, which costs high with low efficiency and inefficient operation.

*Phased Achievements of Hunan Provincial Department of Education Scientific Research Project (15C0962). 


\section{ANALYSIS ON THE ROLE OF HUNAN HG LOGISTICS CENTER CONSTRUCTION}

\section{A. The Promotion of Logistics Center Construction to Economic and Social Development}

The promotion of logistics center construction to economic and social development is mainly reflected in the following aspects:

1) Cultivate new economic growth points: The construction of this project is conducive to logistics industry development function, it will promote the cultivation and development of modern logistics and logistics industry, which will certainly create new economic growth points, and provide new industrial growth support for sustainable economic development.

2) Create an environment for economic development: Accelerating the construction of the logistics center will create a good industrial layout and development environment in the region, and create conditions for attracting investment to improve the level of economic development.

\section{B. The Perfection of Logistics System and Function}

The improvement of regional economic development and urbanization has made the demand for logistics services between regions, central cities, central cities and related areas within the surrounding radiation areas maintain a relatively strong growth trend, and higher requirements were raised on the urban logistics management and organization system.

1) Improve the logistics facility system: Urban construction logistics center, speeding up the construction and development of modern logistics infrastructure, will provide comprehensive infrastructure support for the rational organization of regional logistics due to the coordination of logistics centers in different regions in terms of layout and function.

2) Improve the logistics function system: The connotation of the logistics center determines that the logistics center should be set up in an economic center city or a transportation hub, so developing economic center cities and constructing logistics centers will make the city's logistics infrastructure more complete in layout, division of labor and functions, which is conducive to the rational organization of logistics within the city area of Chenzhou City.

\section{The Improvement of Logistics Efficiency and Enterprise Benefits}

The construction of the logistics center will greatly improve the social logistics environment in the economic region, and create a supporting condition for the wide application of logistics management technology, improve the overall efficiency of social logistics operations, and thus promote the social economic restructuring and economic growth mode, improve the quality of economic growth; the construction and development of logistics centers will create conditions for the specialized division of labor of social logistics services and management organizations, and specialized logistics enterprises will benefit from them, thereby improving the economic benefits of logistics enterprises and providing them with supports for continuous development.

\section{ANALYSIS ON THE NECESSITY OF HUNAN HG LOGISTICS CENTER CONSTRUCTION}

\section{A. The Necessity of Guiding and Transforming the City's Potential Logistics Needs, Especially the Industrial Logistics Needs}

A considerable number of industrial enterprises still maintain a self-centered, traditional business organization model that "to be big and complete" and "to be small and complete". They have not realized that through joint planning and operations, a highly integrated supply chain system will be formed to improve the current production supply and product sales. The construction of Hunan HG Logistics Center will enable urban logistics service facilities and logistics service enterprises to be organically integrated in the construction and operation, so that existing logistics resources can be rationally integrated, and the operational level of infrastructure and its technical equipment can be improved.

\section{B. The Necessity of Supporting the Establishment of an Effective Logistics Market Mechanism}

The construction of Hunan HG Logistics Center will enable all kinds of logistics enterprises operating within the city to establish their own operation control systems and operation organization structure in the center, which is conducive to industry self-discipline and benign competition, and is also beneficial to the monitoring and verification of management department, enable market access and exit and legal system safeguards and enforcement mechanisms to achieve relatively effective monitoring space and monitoring channels in the early stages of their establishment and operation. At the same time, the centralized service operation of Hunan HG Logistics Center can provide useful trials and practices to improve the lack of credit system, reduce logistics transaction costs and improve logistics service efficiency, and help to improve the current unsound business credit, support and strengthen the positive attitude of cargo owners on the demand for logistics services, reduce self-operated logistics, and expand the market demand for logistics services.

Therefore, the construction and operation of Hunan HG Logistics Center will rationalize and scientifically control the market in the city and the important economic center cities around the province, establish a good market order, and form a benign specification and positive guidance for logistics service enterprises, which has a very positive and realistic meaning.

\section{THE EXTERNAL ENVIRONMENT ANALYSIS OF PROJECT CONSTRUCTION}

\section{A. The Favorable Policies of the Logistics Park Issued by the Government Provide Policy Protection for Project Construction}

As an inevitable outcome of the development of modern logistics industry, the logistics park is closely linked to the 
development of the logistics industry. The development of logistics parks has greatly promoted the economic development, the efficiency of logistics enterprises, and the social benefits. In recent years, Chinese governments and enterprises have given strong support to the development of logistics parks. In March 2007, the State Council issued the "Several Opinions on Promoting the Accelerated Development of the Service Industry", which included the development of the logistics industry in key development areas, and proposed "prioritizing the development of the transportation industry, upgrading the professionalization of logistics and social service levels, and vigorously developing the "Third-party logistics", especially as one of the key areas in the modern service industry to accelerate development. In recent years, almost every year, policies to promote the development of the logistics industry have been introduced, providing good policy support for project construction.

\section{B. The Stable Development of the Economic Environment Is the Cornerstone of the Construction of Logistics Centers}

In 2017, the province's regional GDP [2] was 3,459.06 billion yuan, an increase of $8.0 \%$ over the previous year. Among them, the added value of the primary industry was 369 billion yuan, an increase of $3.6 \%$; the added value of the secondary industry was $1,414.55$ billion yuan, an increase of $6.7 \%$; the added value of the tertiary industry was $1,675.51$ billion yuan, an increase of $10.3 \%$. Calculated according to the resident population, the per capita GDP was 50,563 yuan, an increase of $7.4 \%$.

The three industrial structures in the province are 10.7:40.9:48.4. The service industry above designated size achieved operating income of 319.90 billion yuan, an increase of $20.7 \%$ over the previous year; the total profit reached 31.55 billion yuan, an increase of $35.0 \%$. The proportion of the tertiary industry to the regional GDP increased by 2.0 percentage points over the previous year; the industrial added value accounted for $34.3 \%$ of the regional GDP, down 1.6 percentage points over the previous year; the added value of high-tech industries accounted for $23.5 \%$ of the regional GDP, an increase of 1.8 percentage points over the previous year; the added value of the non-public economy is 205.4 .78 billion yuan, an increase of $8.4 \%$, accounting for $59.4 \%$ of the regional GDP; the strategic emerging industry added value of 391.47 billion yuan, an increase of 10.1 . \%, accounting for $11.3 \%$ of the regional GDP, with an increase of 0.7 percentage points over the previous year. The contribution rates of the primary, secondary and tertiary industries to economic growth were $4.9 \%, 37.0 \%$ and $58.1 \%$ respectively. Among them, the contribution rate of industrial added value to economic growth is $33.0 \%$, and the contribution rate of productive service industry to economic growth is $23.7 \%$. The contribution rate of total capital formation, final consumption expenditure, and net outflow of goods and services to economic growth was $48.6 \%$, $53.4 \%$, and $-2.0 \%$ respectively.

\section{ANALYSIS ON THE FEASIBILITY OF PROJECT CONSTRUCTION}

\section{A. Hunan HG Company Has Strong Logistics Strength and Rich Experience in Operation Management}

Hunan HG Logistics Center is a joint-stock logistics enterprise approved by the Municipal Transportation Management Office with a registered capital of 12 million yuan. It has more than 50 freight vehicles and a warehouse area of over 20,000 square meters. It has established Guangzhou, Changsha and Hengyang branch company. So it is a third-party logistics company with high starting point, large scale, strong strength, complete equipment, strict management, strong credit and strong development momentum. It is expected that with the expansion of the company's scale, 250 new freight vehicles will be added in the next five years, reaching the operating scale of 300 freight vehicles and developing into a landmark logistics enterprise.

Hunan HG Logistics has grown rapidly and accumulated rich experience in providing professional third-party logistics services. The logistics supply capacity, financing capacity and market development capability have been greatly improved, reserving good capital, technology and market resources for the company's next development. The company's recent development plan is: on the basis of further integration of the company's existing logistics resources, invest in the construction of a professional, socialized and efficient logistics center. This logistics center will interpret a brand-new modern logistics concept, embodying the characteristics to be large, open, and special with strong radiation, high service level and popularization of new network technologies, which can realize modernization of transactions and globalization of trading scope.

\section{B. Hunan HG Logistics Has a Customer Base Sufficient to Support Project Operations}

Hunan HG Logistics has accumulated a wealth of customer resources. In the past year, Hunan HG Logistics has completed 4 million tons of freight, and has established strategic partnerships and strategic cooperation with major large industrial enterprises and trade circulation enterprises. The enterprises of the agreement mainly include China Resources Power Hunan Co., Ltd., Hunan Jinlei Southern Cement Co., Ltd., Gossberg Digital Technology Co., Ltd., Hunan Shengzhou Yuxiang Flour Industry Co., Ltd., Hunan Chenzhou Grain and Oil Machinery Co., Ltd., etc.

\section{Feasibility of Hunan HG Logistics Center Construction Fund}

Hunan HG Logistics Center has received strong support from government departments at all levels in Hunan Province, providing a solid guarantee for the main channels of fund raising;

The operating entity Hunan HG Logistics Co., Ltd. has been successfully operated and the development trend is good;

It has good conditions for attracting investment and has successfully achieved investment promotion; 
Social funds show high enthusiasm for the modern logistics industry with less risk of operating risks.

\section{Feasibility of the Construction Benefit of Hunan HG Logistics Center}

The benefits of Hunan HG Logistics Center construction are reflected in the two aspects of economic benefits and social benefits, which are reflected in the overall benefits of corporate, government, social and personal benefits.

\section{1) Social benefits}

- It has a profound impact on the development of the logistics industry in the central part of Hunan Province;

- It promotes the rationalization of urban logistics and reduces the total cost of urban logistics;

- It promotes the rational allocation of urban transportation resources, improves transportation efficiency, and reduces unreasonable demand for freight transportation;

- It improves the use value of land and rationally develop land;

- It is conducive to logistics intensive management, optimize the allocation of social resources, create economies of scale, and promote the advancement of logistics technology;

- It increases employment opportunities in the region and promote social stability.

- It improves the overall environment of the city and the overall quality of the city, and it is conducive to the creation of a civilized city.

2) Economic benefits of local and enterprise

- Local fiscal and tax benefits: the taxation of the main logistics industry and the tax increase brought about by the development of related industries;

- Economic benefits of production enterprises: Due to the high level of services brought by modern logistics centers, logistics costs are reduced, thus obtaining "third profit sources" for production enterprises;

- Economic benefits of logistics enterprises: Due to the scale-aggregation effect brought by modern logistics centers, the operating costs of logistics enterprises are reduced, and operating profits are rising;

- Economic benefits of other industries: The construction of logistics centers brings about the development of related service industry enterprises, such as entertainment, catering, culture, tourism, life, auto parts repair, information services and other enterprises;

\section{CONCLUSION}

In summary, the construction of Hunan HG Logistics Center has strong feasibility. Its location has excellent transportation advantages, its land has strong resource advantages, and its investment has considerable comprehensive benefits.

\section{REFERENCES}

[1] Liu Mingfei, Zhang Fangtao. Market demand-oriented urban logistics park planning [J]. Logistics Technology. 2006(04).

[2] Peng Xiaolian. Discussion on the Demand Analysis of Logistics Park [J]. Logistics Technology. 2005(04).

[3] Cheng Mingyong. Discussion on the planning and construction of logistics park [J]. Chinese foreign Entrepreneur. 2012(12) . 